\title{
Eicosadienoic Acid
}

National Cancer Institute

\section{Source}

National Cancer Institute. Eicosadienoic Acid. NCI Thesaurus. Code C68355.

A polyunsaturated long-chain fatty acid with a 20-carbon backbone and exactly 2 double bonds. At least 5 different isomers can be called by this name. 